\title{
Epilepsy in the British Steel Corporation: an evaluation of sickness, accident, and work records
}

\author{
A K DASGUPTA, ${ }^{* 1}$ M SAUNDERS ${ }^{2}$, AND D J DICK $\dagger^{2}$ \\ From the Medical Department, ${ }^{1}$ Teesside Division, British Steel Corporation, Middlesbrough, and the \\ Department of Neurology, ${ }^{2}$ Middlesbrough General Hospital, Middlesbrough, Cleveland, UK
}

ABSTRACT Information relating to sickness, accident, and work records in 45 people with epilepsy employed in the British Steel Corporation was obtained and compared with 38 matched control subjects. Fewer people with epilepsy were prepared to do shift work compared with controls, and prolonged absence from work due to sickness was more frequent in the epileptic group. There was no difference between the two groups in four out of five factors relating to job performance. Those in the epileptic group who had an associated personality disorder had significantly poorer job performance ratings.

The employability of anyone with epilepsy is an individual problem. ${ }^{1}$ The severity and frequency of attacks varies considerably. It is a widely held view that people with epilepsy are more accident prone, have poor attendance records, and are difficult to deal with. ${ }^{2}$ Unfortunately, hard data relating to the employment of people with epilepsy in industry are lacking. ${ }^{3}$ We record the sickness and accident records and job records of known epileptics in the Teesside division of the British Stcel Corporation and compare these where possible with matched controls.

\section{Methods}

\section{GROUP STUDIED}

Fifty-three epileptics were discovered in a total working population of 24000 , giving a prevalence of $0.22 \%$. All patients known to have epilepsy were identified from their medical records. Eight were rejected on the grounds of poor co-operation, doubt about diagnosis, or incomplete information. This left 45 patients, who were designated the epileptic group. All were matched for age, sex, and occupation with mentally and physically fit workers with the exception of seven patients who were working in individual positions within the steel works. For this reason no suitable controls performing the same jobs were available.

\footnotetext{
*Present address: Qr No B/24, Sector 3, Rourkela 769002, Orissa, India.

†Present address: Regional Neurological Centre, Newcastle General Hospital, Newcastle upon Tyne.

Received 17 December 1979

Accepted 16 June 1981
}

MEDICAL INFORMATION

A detailed proforma was completed on each patient detailing the history, frequency, and type of epilepsy, medication and the results of investigations. This information was mainly derived from the medical department of the British Steel Corporation. In addition, case notes and electroencephalographic reports were examined; no further cases of epilepsy were discovered by these means. Patients who had not visited a specialist attended the neurology department with the permission of their general practitioner. The presence or absence of personality disorder, depressive illness, or general medical disease was noted. The severity of epilepsy was classified according to the method of Nussbaum and O'Connor. ${ }^{4}$ This classifies epilepsy on a five-point scale and outlines the frequency and clinical severity of attacks as the criteria for classification (table 1). A note was made of whether the individual was

Table 1 Severity of epilepsy ${ }^{4}$

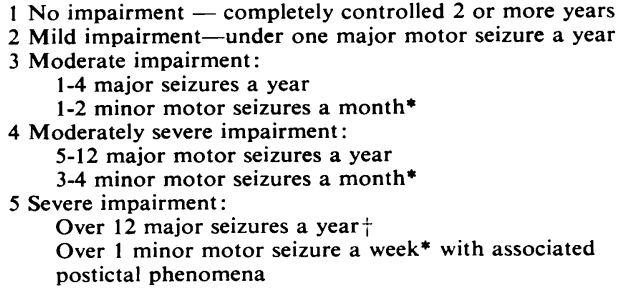

1 No impairment - completely controlled 2 or more years

2 Mild impairment-under one major motor seizure a year

3 Moderate impairment:

1-4 major seizures a year

1-2 minor motor seizures a month*

4 Moderately severe impairment:

5-12 major motor seizures a year

3-4 minor motor seizures a month"

5 Severe impairment:

Over 12 major seizures a year $\dagger$

Over 1 minor motor seizure a week* with associated postictal phenomena

*Includes partial complex, mixed, and petit mal.

+ Not all of which occur in one 90 -day period. 
registered disabled and whether the type of employment in the steel industry had changed because of the diagnosis.

\section{SICKNESS AND ACCIDENT RECORDS}

Sickness and accident records were measured over a one-year period. The frequency of sickness was measured as the number of times an individual was absent from work for at least one day per calendar year. The severity was measured as the total number of days absent a year. For accidents the frequency referred to the number of accidents per employee a year and the severity the number of days lost a year through accident. ${ }^{2}$

JOB PERFORMANCE

Workers' job performance was measured using a merit rating scale ${ }^{5}$ (table 2). This was done by works managers who had no knowledge of medical
British Steel Corporation between one and 20 years. Sixteen people with epilepsy were classified as having no disability, eight were mildly disabled, 17 moderately severely disabled, and two severely disabled. Fifteen people with epilepsy performed non-manual jobs, and of these 8 were unskilled. There was no obvious relationship between the severity of epilepsy and the type of job. Eighteen people had changed their type of job since the diagnosis of epilepsy had become known. There was no relationship between such a change and the severity of the epilepsy.

Only one person in the epileptic group and none in the control group failed to work normal hours. There was no significant difference between the groups in this respect.

Of 45 epileptic workers, 32 did overtime but of the 13 who did not, four were not required to. This left nine people who were required to do overtime but

Table 2 Merit table for job performance ${ }^{5}$

\begin{tabular}{|c|c|c|c|c|c|}
\hline & $\begin{array}{l}\text { Grades } \\
1\end{array}$ & 2 & 3 & 4 & 5 \\
\hline \multicolumn{6}{|l|}{ Quality of work } \\
\hline \multirow{3}{*}{$\begin{array}{l}\text { Accuracy, economy, } \\
\text { neatness, etc } \\
\text { Quantity of work }\end{array}$} & Consistently superior & Sometimes superior & $\begin{array}{l}\text { Consistently } \\
\text { satisfactory }\end{array}$ & Usually acceptable & $\begin{array}{l}\text { Consistently } \\
\text { unsatisfactory }\end{array}$ \\
\hline & & Often above standard & Meets standard & & \\
\hline & standard & Uilen auove stalidald & vieets stamuard & standard & standard \\
\hline \multicolumn{6}{|l|}{ Dependability } \\
\hline $\begin{array}{l}\text { Punctuality, } \\
\text { judgment, follows } \\
\text { instructions }\end{array}$ & High in all respects & High in some respects & Satisfactory & $\begin{array}{l}\text { Sometimes } \\
\text { undependable }\end{array}$ & $\begin{array}{l}\text { Consistently } \\
\text { undependable }\end{array}$ \\
\hline \multicolumn{6}{|l|}{ Attitude } \\
\hline $\begin{array}{l}\text { Toward company, } \\
\text { other employees, } \\
\text { supervisor }\end{array}$ & $\begin{array}{l}\text { Inspires others to work } \\
\text { as a team }\end{array}$ & $\begin{array}{l}\text { Quick to volunteer or } \\
\text { help others }\end{array}$ & $\begin{array}{l}\text { Co-operative as } \\
\text { general rule }\end{array}$ & $\begin{array}{l}\text { Works well with } \\
\text { some and not others }\end{array}$ & $\begin{array}{l}\text { Works poorly with } \\
\text { others }\end{array}$ \\
\hline \multicolumn{6}{|l|}{ Safety } \\
\hline $\begin{array}{l}\text { Respect for rules, } \\
\text { influence on others }\end{array}$ & $\begin{array}{l}\text { Leads in promoting } \\
\text { safety }\end{array}$ & $\begin{array}{l}\text { Goes out of way to be } \\
\text { safe }\end{array}$ & Respects rules & $\begin{array}{l}\text { Sometimes violates } \\
\text { safety }\end{array}$ & Disregards safety \\
\hline
\end{tabular}

records. The scale measures five factors: quality, quantity, dependability, attitude, and safety on a five-point scale, a low score indicating a good performance.

\section{Results}

The analysis related to 45 people with epilepsy and 38 matched controls. An overall comparison of the epileptic and control groups was made. Where appropriate, a matched comparison within the severity ratings of the epileptic group was made with the control group. Within the epileptic group, a comparison was made between different grades of severity.

Among the 45 people with epilepsy only eight had been registered disabled at any time and five were currently registered disabled. The people in the epileptic group had been in employment in the who were reluctant to do so. Thirty-three of 38 controls did overtime and of the five who did not, two were not required to. Of the remaining three controls who did not do overtime, two were reluctant to do so. There was no significant difference between the two groups in this respect.

Twenty out of 45 workers with epilepsy did shift work and of the 25 who did not, 13 were not required to. Thus 20 out of 32 epileptic workers were eligible for and did shift work. Of the 12 who did not, all were reluctant to do so. Thirty-one out of 38 controls did shift work but none of the seven who did not were required to. The difference between these two groups is significant $(\mathrm{p}=<0.01)$ and the findings are summarised in table 3 .

Eleven out of 45 workers in the epileptic group were never absent due to sickness, compared with 13 of the 38 controls. This difference is not significant. When the epileptic group was considered alone, 
Table 3 Shiftwork in epilepsy and control groups

\begin{tabular}{llll}
\hline & Epilepsy & Control & Total \\
\hline Did shiftwork & 20 & 31 & 51 \\
Did not & 12 & 0 & 12 \\
Total & 32 & 31 & 63 \\
\hline
\end{tabular}

Chi squared $=14.4$.

$\mathrm{p}=<0.01$.

there was no difference within the severity groups. With regard to absence severity, if absences of under 20 days were considered there was no significant difference between the two groups. Absences of over 20 days, however, occurred more often in the epileptic group $(\mathrm{p}=<0.05)$ (table 4$)$.

There was no significant difference between the

Table 4 Sickness severity

\begin{tabular}{llcl}
\hline Absence & Epilepsy & Control & Total \\
\hline$<20$ days & 24 & 30 & 54 \\
$\geqslant 20$ days & 21 & 8 & 29 \\
Total & 45 & 38 & 83
\end{tabular}

Chi squared $=5.95$.

$\mathrm{p}=<0.05$.

two groups with regard to accident frequency and severity. Of 45 epileptic workers 31 had no accidents compared with 31 out of 38 controls.

Work performance according to the five criteria used were compared in the overall epileptic and control groups. Because of small numbers, groups 1 and 2 (above average), 3 and 4 (average), and 5 (below average) were used in the analysis. Using this method, only dependability showed any difference between the two groups (table 5). There was no evidence of a significant difference between the

Table 5 Dependability scores in epilepsy and control groups

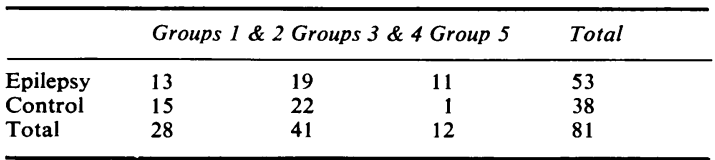

Chi squared $=8.42$ on 2 degrees of freedom.

$\mathrm{p}=<0.02$.

number of anticonvulsants taken and work performance.

Within the epileptic group, when the five work factors were analysed in association with presence or absence of a personality disorder, there was a significant association between the presence of this factor and poor work performance. For the purposes of this analysis, grades 1, 2, and 3 were aggregated compared with grades 4 and 5 (table 6).
Table 6 Job performance and presence or absence of personality disorder

\begin{tabular}{llccl}
\hline & $\begin{array}{l}\text { Personality } \\
\text { disorder }\end{array}$ & $\begin{array}{c}\text { Grades } \\
1,2, \& 3\end{array}$ & $\begin{array}{l}\text { Grades } \\
4 \& 5\end{array}$ & \\
\hline Quality & Present & 1 & 5 & $\mathrm{p}=<0.05$ \\
Quantity & Absent & 27 & 10 & $\mathrm{p}=<0.01$ \\
& Present & 1 & 5 & $\mathrm{p}=<0.01$ \\
DependabilityPresent & Absent & 32 & 5 & $\mathrm{p}=<0.05$ \\
\multirow{5}{*}{ Attitude } & Absent & 31 & 5 & $\mathrm{p}=<0.05$ \\
& Present & 2 & 4 & \\
Safety & Absent & 29 & 8 & \\
& Present & 4 & 2 & \\
& Absent & 36 & 1 &
\end{tabular}

\section{Discussion}

The prevalence of epilepsy in the steel industry in this study was $0.22 \%$, which compares with a figure of $0.39 \%$ recorded from a steel works in Wales. ${ }^{6}$ In a survey of epilepsy and employment McIntyre $^{3}$ gave an average figure for his study of $0.12 \%$ in various industries. If one assumes a prevalence in the general population, the figure of $0.5 \%$ in our study would seem to be a reasonable assessment of the true prevalence within the industry examined.

Eighteen out of 45 people studied in detail had changed their jobs during the course of employment in the industry. On each occasion this had been on medical advice. In that sense over one-third of the people studied could be said to have had difficulty with employment. However, they were found more suitable jobs within the same industry, where there is a wide variety of employment available.

Comparison between the treatment and control groups showed that people with epilepsy were more reluctant to do shift work. This is almost certainly due to problems epileptics may have in managing their anticonvulsant regimen when doing shift work. The problem is often apparent rather than real, but medical advice against shift work is commonly given.

Our figures show that there was no significant difference between treatment and control groups with regard to overall sickness and accident records. There was a difference in sickness records when absences of 20 days or more were considered, but this was due to illness unrelated to epilepsy. There was no evidence that people with more severe forms of epilepsy had worse records of accident or sickness.

An analysis of job performance between epileptic and control groups showed no major overall difference when using five-job performance factors. When the medical records indicated the presence of a personality disorder, however, work performance was significantly reduced in that group when compared with the remainder of the epileptic group. This applied to all five work factors considered. 
These findings are in broad agreement with the findings of Udel' ${ }^{2}$ on the work performance of epileptics in four companies.

The results of our study are encouraging. One must accept that some degree of selection has to be applied when employing people with epilepsy in industry, but the overall performance of the epileptic group compared with their colleagues is satisfactory.

We thank Dr A M Leach, Dr D Eglin, and the staff of the medical department of the British Steel Corporation; Mr Angus MacNay for statistical help; Miss J Whinn and Mrs R Dick for secretarial help and Mrs C Goult, our librarian.

\section{References}

${ }^{1}$ Whitty CWM. Employability of the epileptic. Transactions of the Society of Occupational Medicine 1968;18:75-7.

2 Udel MM. The work performance of epileptics in industry. Arch Environ Health 1960;1:257-64.

${ }^{3}$ McIntyre I. Epilepsy and employment. Community Health (Bristol) 1976;7:195.

4 Nussbaum K, O'Connor JS. Impairment severity in seizure disorders: some suggestions for reliable assessment. JOM 1977;19:615-8.

${ }^{5}$ Maher RF. Psychology in industry. 3rd ed. London: Harrap, 1965.

6 Jones JG. Employment of epileptics. Lancet 1965; ;ii:486-9. 